\title{
Methylseleninic acid (MSA) inhibits 17ß-estradiol-induced cell growth in breast cancer T47D cells via enhancement of the antioxidative thioredoxin/ thioredoxin reductase system
}

\author{
Tomofumi OKuno ${ }^{1}$, Kiyoshi MiURa ${ }^{1}$, Fumitoshi SAKazAKI ${ }^{2}$, Katsuhiko NaKamuro ${ }^{3}$, and Hitoshi Ueno ${ }^{1}$ \\ ${ }^{1}$ Department of Public Health \& Preventive Pharmacology, Faculty of Pharmaceutical Sciences, Setsunan University, 45-1, Nagaotoge- \\ cho, Hirakata, Osaka 573-0101, Japan; ${ }^{2}$ Laboratory of Toxicology, Faculty of Pharmacy, Osaka Ohtani University, 3-11-1 Nishikiori- \\ Kita, Tondabayashi, Osaka 584-8540, Japan; and ${ }^{3}$ Department of Life Sciences, Faculty of Science and Engineering, Setsunan University, \\ 17-8 Ikeda-Nakamachi, Neyagawa, Osaka 572-8508, Japan
}

(Received 6 April 2012; and accepted 16 May 2012)

\begin{abstract}
The purpose of this study was to clarify the cell growth inhibitory mechanism of human breast cancer cells caused by selenium $(\mathrm{Se})$ compounds. In the presence of $17 \beta$-estradiol $\left(\mathrm{E}_{2}\right)$ at physiological concentrations, growth of estrogen receptor $\alpha(\mathrm{ER} \alpha)$-positive T47D cells was markedly inhibited by $1 \times 10^{-6} \mathrm{~mol} / \mathrm{L}$ methylseleninic acid (MSA) with no Se related toxicity. Under conditions where cell growth was inhibited, MSA decreased ER $\alpha$ mRNA levels and subsequent protein levels; further decreasing expression of estrogen-responsive finger protein (Efp) which is a target gene product of ER $\alpha$ and promotes G2/M progression of the cell cycle. Therefore, the decline in Efp expression is presumed to be involved in G2 arrest. Coincidentally, the antioxidative thioredoxin/thioredoxin reductase (Trx/TrxR) system in cells was enhanced by the synergistic action of $\mathrm{E}_{2}$ and MSA. It has been reported that ROS-induced oxidative stress enhanced ER $\alpha$ expression. $\mathrm{E}_{2}$ increased production of intracellular ROS in T47D cells. Meanwhile, MSA significantly decreased $\mathrm{E}_{2}$-induced ROS accumulation. From these results, activation of the Trx/TrxR system induced by the coexistence of MSA and $E_{2}$ suppresses oxidative stress and decreases expression of ER $\alpha$, and finally induces the growth arrest of T47D cells through disruption of ER $\alpha$ signaling.
\end{abstract}

Breast cancer, the most common cancer in women, is classically an hormone-dependent cancer. Prolonged exposure to estrogen is a major risk for breast cancer (15). In Japan, the incidence of breast cancer among women has increased over the past three decades $(10,34)$. The Monitoring of Cancer Incidence in Japan (MCIJ) estimated that more than 49,000 Japanese women were diagnosed with breast cancer in 2006 (20).

Estrogen such as $17 \beta$-estradiol $\left(\mathrm{E}_{2}\right)$ is known to

Address correspondence to: Tomofumi Okuno, $\mathrm{PhD}$ Faculty of Pharmaceutical Sciences, Setsunan University, 45-1 Nagaotoge-cho, Hirakata, Osaka 573-0101, Japan

Tel: +81-72-866-3121, Fax: +81-72-866-3166

E-mail: okuno@pharm.setsunan.ac.jp promote cell growth of breast cancer through binding to its cognate receptor, estrogen receptors (ERs) $(18,28,29,36,40)$. At present, there are at least two different forms of ERs, usually referred to as $\mathrm{ER} \alpha$ and $\mathrm{ER} \beta$ (39). Approximately two-thirds of all breast cancers express the ER $\alpha$ protein at the time of diagnosis (4). ER $\alpha$ is a ligand-transcriptional factor that belongs to the nuclear steroid/thyroid hormone receptor family (6). The classic mechanism of action of ER $\alpha$ has been proposed as follows: Upon binding of $\mathrm{E}_{2}, \mathrm{ER} \alpha$ undergoes conformational changes. Following dimerization, ER $\alpha$ binds to estrogen response elements (ERE) located in the promoter regions of estrogen-regulated genes to modulate expression of genes related to estrogenresponsive cell proliferation (39). In addition, ER $\alpha$ can mediate transcription of other target genes, 
through protein-protein interactions with other transcriptional factors such as activator protein-1 (AP-1) $(13,22)$. ER $\alpha$ signaling is closely related to cell growth of ER $\alpha$-positive breast cancer cells.

Oxidative stress induced by reactive oxygen species (ROS) has been reported to modulate ER $\alpha$ expression in various cell lines. In human breast cancer MCF-7 cells, $\mathrm{H}_{2} \mathrm{O}_{2}$ increased $\mathrm{ER} \alpha$ protein levels (37). Endogenous $\mathrm{E}_{2}$ undergoes oxidative metabolism and generates ROS that include a number of chemically reactive oxygen derivatives such as the superoxide anion $\left(\mathrm{O}_{2}^{-\bullet}\right)$, hydrogen peroxide $\left(\mathrm{H}_{2} \mathrm{O}_{2}\right)$, and the hydroxyl radical $\left(\mathrm{OH}^{\bullet}\right)(22)$.

The essential micronutrient selenium (Se) has beneficial effects in inhibiting cancer growth. Several clinical trials using Se-enriched yeast showed the protective effects of Se against prostate, lung, and colon cancers $(3,5)$. These trials failed to detect a significant change in breast cancer risk. One reason might be attributable to the fact that there were too few breast cancer cases in the cohorts to provide sufficient statistical power for a conclusive analysis of the data. Previous reports, however, showed the efficacy of Se chemoprevention in animal mammary tumor models (21) and human breast cancer cell lines (31). In ER $\alpha$-positive MCF-7 breast cancer cells, methylseleninic acid $\left(\mathrm{CH}_{3} \mathrm{SeO}_{2} \mathrm{H}\right.$, abbreviated as MSA) inhibited cell growth and ER $\alpha$-mediated gene transcription by decreasing ER $\alpha$ mRNA levels and subsequent protein levels (33). The disruption of ER $\alpha$ signaling induced by MSA is likely a major mechanism of MCF-7 cell growth inhibition. However, the mechanism that MSA uses to suppress $\mathrm{ER} \alpha$ expression is still unknown. It is also unclear how Se compounds affect the growth of other breast cancer cells with varying $\mathrm{ER} \alpha$ expression in the presence of $E_{2}$.

In the present study, we first investigated the growth inhibitory effect of various Se compounds against ER $\alpha$-positive T47D cells derived from human mammary gland ducts. We found that MSA at $1 \times 10^{-6} \mathrm{~mol} / \mathrm{L}$ strongly inhibited $\mathrm{E}_{2}$-induced cell growth in comparison with other selenium compounds. MSA was accompanied by decreases in $\mathrm{ER} \alpha \mathrm{mRNA}$ levels and resulting protein levels, and finally caused cell cycle arrest as a result of disruptions in ER $\alpha$ signaling. We further investigated the mechanism by which MSA decreases expression levels of the ER $\alpha$ protein. Our results suggested that MSA decreased $\mathrm{E}_{2}$-induced intracellular ROS levels through activation of the thioredoxin/thioredoxin reductase (Trx/TrxR) system, but not the glutathione/ glutathione peroxidase 1 (GSH/GPx1) system, and inhibited ER $\alpha$ expression.

\section{MATERIALS AND METHODS}

Chemicals. Sodium selenite $\left(\mathrm{Na}_{2} \mathrm{SeO}_{3}\right)$, sodium selenide $\left(\mathrm{Na}_{2} \mathrm{Se}\right)$, selenocysteine, selenocystamine, and MSA were obtained from Sigma-Aldrich Co. LLC. (St Louis, MO). Selenomethionine and Se-methylselenocysteine were purchased from Acros Organics (Geel, Belgium). Sodium selenite $\left(\mathrm{Na}_{2} \mathrm{SeO}_{4}\right)$ and sodium dioxide $\left(\mathrm{SeO}_{2}\right)$ were from Kanto Chemical Co. Inc. (Tokyo, Japan). All other reagents were of the highest grade commercially available.

Antibodies. Antibodies against ER $\alpha$ were purchased from Medical \& Biological Laboratories Co., Ltd. (Nagoya, Japan), and TrxR-1 and Trx were from LabFrontier (Seoul, Korea). Efp and $\beta$-actin were obtained from BD Biosciences (Franklin Lakes, NJ) and Novus Biologicals, LLC (Littleton, CO), respectively. HRP-conjugated secondary antibody was obtained from Cell Signaling Technology, Inc. (Beverly, MA).

Removal of sex steroids in serum. We removed sex steroids from fetal bovine serum (FBS) by charcoaldextran stripping (23). Briefly, a suspension of 5\% charcoal with $0.5 \%$ dextran was prepared. Aliquots of charcoal-dextran suspension of a volume similar to the serum aliquot to be processed were centrifuged at $1,000 \times g$ for $10 \mathrm{~min}$. Supernatants were aspirated, and serum aliquots were mixed with charcoal pellets. This charcoal-serum mixture was maintained in suspension by rolling at 6 cycles $/ \mathrm{min}$ at $37^{\circ} \mathrm{C}$ for $1 \mathrm{~h}$. The suspension was centrifuged at $1,000 \times \mathrm{g}$ for $20 \mathrm{~min}$, and the supernatant was then filtered through a $0.20 \mu \mathrm{m}$ filter. Charcoal dextrantreated serum (CDFBS) was stored at $-80^{\circ} \mathrm{C}$ until needed.

Cell lines and culture conditions. Human breast cancer T47D cells were cultured in Dulbecco's modification of Eagle's medium (DMEM) supplemented with 5\% FBS and maintained in an atmosphere of $5 \% \mathrm{CO}_{2}$ in a $37^{\circ} \mathrm{C}$ humidified incubator.

DNA determination by ethidium bromide fluorescence method. Cells were plated in 98-well plates (Nunc A/S, Roskilde, Denmark) at initial concentrations of $2.5 \times 10^{4}$ cells/well in 5\% CDFBS-supplemented phenol red-free DMEM. Cells were allowed to attach for $24 \mathrm{~h}$, and the different concentrations of $\mathrm{E}_{2}$ and Se compounds were added. After 0-4 
days culture, total DNA amounts in growth cells were determined by the ethidium bromide fluorescence method (32). Plates were centrifuged at $4^{\circ} \mathrm{C}$, $320 \times \mathrm{g}$ for $15 \mathrm{~min}$ and supernatants were removed. Cells were washed once with $200 \mu \mathrm{L}$ of PBS and $200 \mu \mathrm{L}$ of $0.05 \%$ SDS was added and left for $30 \mathrm{~min}$ to lyse the cells. Then, $100 \mu \mathrm{L}$ of $50 \mathrm{mg} / \mathrm{mL}$ ethidium bromide was added to each well, left for 30 min, and DNA-ethidium bromide complex was determined fluorometrically at Ex. $515 \mathrm{~nm}$ and Em. $620 \mathrm{~nm}$ as an indication of cell numbers.

Semi quantitative reverse transcription-polymerase chain reaction ( $R T-P C R)$. Cells were seeded in a $90 \mathrm{~mm}$ tissue culture dish (BD Falcon, Durham, $\mathrm{NC)}$ at an initial concentration of $4 \times 10^{6}$ cells/dish in 5\% CDFBS-supplemented phenol red-free DMEM. At $24 \mathrm{~h}$ after seeding, cells were exposed to $1 \times 10^{-9} \mathrm{~mol} / \mathrm{L} \mathrm{E}_{2}$ and $1 \times 10^{-6} \mathrm{~mol} / \mathrm{L} \mathrm{MSA}$ for 4 days. Total RNA from cells was isolated using TRIzol Reagent (Life Technologies Co., Gaithersburg, MD) according to the manufacturer's protocols and quantified spectrophotometrically. Total RNA $(1 \mu \mathrm{g})$ of each sample was reverse-transcribed using the SuperScript First Standard System (Life Technologies Co.) according to the manufacturer's instructions. The primers for amplification during PCR were designed according to a previously published report (19). The following primer pairs were used to amplify ER $\alpha$ and $\beta$-actin respectively: (sense) 5'-TACTGCATCAGATCCAAGGG-3'/(antisense) 5'-ATCAATGGTGCACTGGTTGG-3'; (sense) 5'-GTGGGGCGCCCCAGGCACCA- 3'/(antisense) 5'-CTTCCTTAATGTCACGCACGATT TC-3'. For RCRs, $1 \mu \mathrm{L}$ of cDNA, $8 \mu \mathrm{L}$ of $25 \mathrm{mmol} /$ $\mathrm{L} \mathrm{MgCl}_{2}, 8 \mu \mathrm{L}$ of $2.5 \mathrm{mmol} / \mathrm{L}$ dNTP mix, $10 \mu \mathrm{L}$ of $10 \times$ Ex Taq buffer solution (Takara Shuzo Co. Ltd., Shiga, Japan), $0.5 \mu \mathrm{L}$ of $5 \mathrm{U} / \mu \mathrm{L}$ Ex Taq DNA polymerase (Takara Shuzo Co. Ltd.), $1 \mu \mathrm{L}$ of $50 \mu \mathrm{mol} / \mathrm{L}$ gene specific primers as described above, and were mixed with $70.5 \mu \mathrm{L}$ of DEPC- $\mathrm{H}_{2} \mathrm{O}$ in a $200 \mu \mathrm{L}$ PCR tube. PCR was performed with the PCR thermal cycler MP (Takara Shuzo Co. Ltd.). Cycling conditions for $\mathrm{ER} \alpha$ were carried out with the first denaturation step at $95^{\circ} \mathrm{C}$ for $6 \mathrm{~min}$ and $94^{\circ} \mathrm{C}$ for $1 \mathrm{~min}$, followed by 40 cycles at $94^{\circ} \mathrm{C}$ for $1 \mathrm{~min}$, $55^{\circ} \mathrm{C}$ for $1 \mathrm{~min}, 72^{\circ} \mathrm{C}$ for $1 \mathrm{~min}$, and then a final extension step at $72^{\circ} \mathrm{C}$ for $10 \mathrm{~min}$. Cycling conditions for $\beta$-action were carried out with the first denaturation step at $94^{\circ} \mathrm{C}$ for $2 \mathrm{~min}$, followed by 30 cycles at $94^{\circ} \mathrm{C}$ for $45 \mathrm{~s}, 60^{\circ} \mathrm{C}$ for $45 \mathrm{~s}, 72^{\circ} \mathrm{C}$ for $45 \mathrm{~s}$, and then a final extension step at $72^{\circ} \mathrm{C}$ for $10 \mathrm{~min}$. PCR products were electrophoresed on a $2 \%$ agarose gel, visualized with ethidium bromide, and the intensity of each band was quantitated with Light-Capture and a CS Analyzer (Atto Co., Tokyo). The RT-PCR signal obtained for each gene was normalized to that for $\beta$-actin.

Western blot. Cells were seeded in a $90 \mathrm{~mm}$ dish at an initial concentration of $4 \times 10^{6}$ cells/dish in $5 \%$ CDFBS-supplemented phenol red-free DMEM. Cells were allowed to attach for $24 \mathrm{~h}$, and then both $1 \times$ $10^{-9} \mathrm{~mol} / \mathrm{L} \mathrm{E}_{2}$ and $1 \times 10^{-6} \mathrm{~mol} / \mathrm{L}$ MSA were exposed for 4 days. For extraction of total cell proteins, cells were washed with precooled PBS and subsequently lysed in precooled lysis buffer $(10 \mathrm{mmol} / \mathrm{L}$ Tris-HCl, pH 7.5, $150 \mathrm{mmol} / \mathrm{L} \mathrm{NaCl}, 0.5 \%$ Nonidet $\mathrm{P}-40,1 \mathrm{mmol} / \mathrm{L}$ phenylmethylsulfonyl fluoride, $0.11 \mathrm{unit} / \mathrm{mL}$ trypsin inhibitor). Cell lysis was performed on ice for $30 \mathrm{~min}$ and was centrifuged at $4^{\circ} \mathrm{C}, 18,500 \times \mathrm{g}$ for $30 \mathrm{~min}$, and supernatants were obtained. Protein concentrations of supernatants were measured using a BCA protein assay reagent kit (Thermo Fisher Scientific K.K., Yokohama, Japan). Aliquots of protein extract and $2 \times$ Leammli sample buffer were mixed and boiled for $5 \mathrm{~min}$. Aliquots of protein solution were analyzed on $2 \%$ polyacrylamide gels and transferred onto polyvinylidene fluoride (PVDF) membranes. For immunoblotting, PVDF membranes were incubated with specific antibodies recognizing target proteins for $2 \mathrm{~h}$ at room temperature. Membranes were then incubated with HRP-conjugated secondary antibody for $1 \mathrm{~h}$ at room temperature and subsequently analyzed by enhanced chemiluminescence (ECL) western blotting detection reagent (GE Healthcare Bio-Sciences AB, Uppsala, Sweden) and visualized by Light-Capture. The intensity of each band was quantitated with a CS Analyzer. $\beta$-Actin was used as a loading control.

Enzyme activity. Cells were seeded in a $90 \mathrm{~mm}$ dish at an initial concentration of $4 \times 10^{6}$ cells/dish in $5 \%$ CDFBS-supplemented phenol red-free DMEM. At $24 \mathrm{~h}$ after seeding, cells were exposed to $1 \times$ $10^{-9} \mathrm{~mol} / \mathrm{L} \mathrm{E}_{2}$ and $1 \times 10^{-6} \mathrm{~mol} / \mathrm{L}$ MSA for 4 days. Cultured cells were washed once with PBS after centrifugation at $900 \times \mathrm{g}$ for $10 \mathrm{~min}$ at $4{ }^{\circ} \mathrm{C}$. Cells were suspended in $0.2 \%$ Triton-X $50 \mathrm{mmol} / \mathrm{L}$ phosphate buffer ( $\mathrm{pH}$ 7.0), followed by one cycle of freezing and thawing. After centrifugation at $13,000 \times g$ for $15 \mathrm{~min}$ at $4^{\circ} \mathrm{C}$, the supernatant was dialyzed with $8,000 \mathrm{M}$.W.-cut-off membrane against $50 \mathrm{mmol} / \mathrm{L}$ phosphate buffer ( $\mathrm{pH}$ 7.0) to remove endogenous thiol substances.

GPx1 activity was determined according to the 
coupled enzymatic method with a slight modification (42). The assay mixture contained $0.2 \mathrm{mmol} / \mathrm{L}$ NADPH, $0.5 \mathrm{mmol} / \mathrm{L}$ EDTA, $0.2 \mathrm{mmol} / \mathrm{L} \mathrm{NaN}_{3}$, $2 \mathrm{mmol} / \mathrm{L} \mathrm{GSH}, 1 \mathrm{unit} / \mathrm{mL}$ of GSH reductase, $10 \mathrm{mmol} /$ $\mathrm{L}$ phosphate buffer ( $\mathrm{pH} 7.0$ ), and $0.015 \mathrm{mmol} / \mathrm{L}$ hydrogen peroxide as the substrate in a total volume of $1 \mathrm{~mL}$ including a dialyzed sample. GPx 1 activity was calculated by measuring absorbance at $340 \mathrm{~nm}$. Protein was determined using a BSA protein assay reagent kit.

To measure TrxR activity, the dialyzate was heated at $55^{\circ} \mathrm{C}$ for $10 \mathrm{~min}$ to inactivate heat-instable thiol-reduction enzymes. The sample was cooled and centrifuged at $13,000 \times g$ for $30 \mathrm{~min}$ at $4^{\circ} \mathrm{C}$. TrxR activity was determined by a spectrophotometric insulin-reduction assay $(9,11)$. The assay mixture contained $0.8 \mathrm{mmol} / \mathrm{L} \mathrm{NADPH}, 0.34 \mathrm{mmol} / \mathrm{L}$ insulin, $4.5 \mathrm{mmol} / \mathrm{L}$ EDTA-2Na, $90 \mathrm{mmol} / \mathrm{L}$ HEPES buffer (pH 7.0), and with or without $4.5 \mu \mathrm{mol} / \mathrm{L}$ E. coli $\mathrm{Trx}$ in $200 \mu \mathrm{L}$. The mixture was started by addition of $100 \mu \mathrm{L}$ of the supernatant sample at $37^{\circ} \mathrm{C}$, incubated for $60 \mathrm{~min}$, and stopped by the addition of $750 \mu \mathrm{L}$ of $0.3 \mathrm{mg} / \mathrm{mL}$ DTNB- $6 \mathrm{~mol} / \mathrm{L}$ guanidine hydrochloride- $0.2 \mathrm{~mol} / \mathrm{L}$ Tris- $\mathrm{HCl}(\mathrm{pH} 8.0)$. TrxR activity was calculated by measuring absorbance at $412 \mathrm{~nm}$. Protein was determined using a BSA protein assay reagent kit.

Determination of GSH. GSH content was determined by HPLC using SBD-F as a fluorescent reagent according to the method described in a previous report (38).

Determination of ROS by flow cytometry. Cells were seeded in a $90 \mathrm{~mm}$ dish at an initial concentration of $4 \times 10^{6}$ cells/dish in $5 \%$ CDFBS-supplemented phenol red-free DMEM. At $24 \mathrm{~h}$ after seeding, $1 \times$ $10^{-9} \mathrm{~mol} / \mathrm{L} \mathrm{E}_{2}$ and $1 \times 10^{-6} \mathrm{~mol} / \mathrm{L}$ MSA were exposed for $0,6,12$, and $24 \mathrm{~h}$. Intracellular ROS levels were detected by flow cytometry using carboxy dichlorofluorescein diacetate (carboxy DCFH-DA) as described previously (2). Cells (10,000 cells measured) were analyzed in a flow cytometer (JASCO Co., Tokyo).

Statistical analysis. Statistical analyses were carried out using Origin 7.5 software (OriginLab, USA). A student's $t$-test was used to determine the significance between treatments and untreated controls, and $P<0.05$ was considered significant.

\section{RESULTS}

Effect of Se compounds on T47D cell growth in the presence of $E_{2}$

The inhibitory effects of Se compounds on the growth of ERa-positive T47D cells were investigated. $E_{2}$ promoted the growth of T47D cells in a concentration-dependent manner. At 4 days, a physiological concentration of $1 \times 10^{-9} \mathrm{~mol} / \mathrm{L} \mathrm{E}_{2}$ increased the cell number to about 3 -fold of untreated controls. Meanwhile, $\mathrm{Na}_{2} \mathrm{SeO}_{3}$, selenomethionine or MSA at each concentration of $1 \times 10^{-6} \mathrm{~mol} / \mathrm{L}$ significantly inhibited $\mathrm{E}_{2}$-induced cell number accumulation in the presence of $E_{2}$ (Table 1). Because MSA strongly inhibited $\mathrm{E}_{2}$-induced cell growth, we chose MSA to further elucidate the inhibitory mechanism of cell growth. As shown in Fig. 1, MSA inhibited

Table 1 Effect of various Se compounds on the growth of $E_{2}$-induced T47D cells

\begin{tabular}{lc}
\hline \multicolumn{1}{c}{$\begin{array}{c}\text { Se compounds } \\
\left(1 \times 10^{-6} \mathrm{~mol} / \mathrm{L}\right)\end{array}$} & $\begin{array}{c}\text { Cell growth rate } \\
(\%)\end{array}$ \\
\hline $\mathrm{Control}_{\mathrm{Na}} \mathrm{SeO}_{3}$ & $100.0 \pm 1.0$ \\
$\mathrm{Na}_{2} \mathrm{SeO}_{4}$ & $82.7 \pm 1.1^{*}$ \\
$\mathrm{Na}_{2} \mathrm{Se}$ & $90.3 \pm 11.2$ \\
$\mathrm{SeO}_{2}$ & $99.2 \pm 7.5$ \\
$\mathrm{Selenomethionine}$ & $100.8 \pm 11.3$ \\
$\mathrm{Se}-$ Methylselenocysteine & $79.9 \pm 4.5^{*}$ \\
Selenocystine & $99.2 \pm 6.8$ \\
Selenocystamine & $98.2 \pm 8.8$ \\
MSA & $90.1 \pm 8.1$ \\
\hline
\end{tabular}

$\mathrm{E}_{2}$ was exposed at the concentration of $1 \times 10^{-9} \mathrm{~mol} / \mathrm{L}$.

Values are mean $\pm \mathrm{SD}(n=6)$.

*Significantly different from the control $(P<0.01)$.

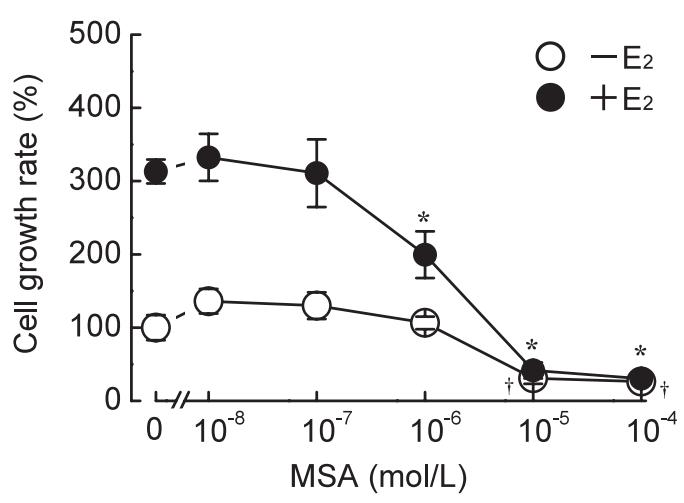

Fig. 1 Dose-response effect of MSA on $E_{2}$-induced cell growth of T47D cells. Values are mean \pm SD $(n=4-5) . E_{2}$ was exposed at $1 \times 10^{-9} \mathrm{~mol} / \mathrm{L}$. * Significantly different from the $\mathrm{E}_{2}$-induced control group $(P<0.01) .{ }^{\dagger}$ Significantly different from the untreated control group $(P<0.01)$. 
$\mathrm{E}_{2}$-induced cell growth in a concentration-dependent manner. No effect on cell growth was seen up to a concentration of $1 \times 10^{-7} \mathrm{~mol} / \mathrm{L}$. Beyond this concentration, MSA significantly inhibited cell growth in the presence of $E_{2}$. After treatment with greater than $1 \times 10^{-5} \mathrm{~mol} / \mathrm{L}$ MSA, a strong inhibitory effect against T47D cells was observed regardless of the existence of $E_{2}$. This effect was presumed to be mediated by Se related toxicity. Interestingly, MSA at a concentration of $1 \times 10^{-6} \mathrm{~mol} / \mathrm{L}$ specifically inhibited cell growth in the presence of $\mathrm{E}_{2}$, and exhibited no Seinduced toxicity. From these results, inhibition caused by MSA at a concentration of $1 \times 10^{-6} \mathrm{~mol} / \mathrm{L}$ may be closely related to the mechanism of $E_{2}-$ dependent cell growth.

Expression of ERa $m R N A$ and protein by treatment with $E_{2}$ plus MSA

To determine whether ER $\alpha$ is related to the inhibition of cell growth caused by MSA, expression of $\mathrm{ER} \alpha$ in T47D cells was measured by RT-PCR and Western blotting. As shown in Fig. 2, 4 days after treatment with $1 \times 10^{-9} \mathrm{~mol} / \mathrm{L} \mathrm{E}$, expression levels of ER $\alpha \mathrm{mRNA}$ and ER $\alpha$ protein increased to $160 \%$ and $165 \%$ of untreated controls, respectively. These results suggest that the increase in ER $\alpha$ expression plays key roles in $\mathrm{E}_{2}$-dependent cell growth. On the other hand, the combination of MSA, at a concentration of $1 \times 10^{-6} \mathrm{~mol} / \mathrm{L}$, with $\mathrm{E}_{2}$ did not increase expression levels of ER $\alpha$ mRNA or ER $\alpha$ protein over that of untreated controls (Fig. 2). Furthermore, it was recognized that MSA at concentrations between $1 \times 10^{-7}$ and $1 \times 10^{-6} \mathrm{~mol} / \mathrm{L}$ decreased expression of ER $\alpha$ protein in a dose-dependent manner (data not shown). It was also found that MSA-induced inhibition of cell growth recovered by about $20 \%$ in T47D cells knocked down for ER by siRNA in the presence of $E_{2}$. Expression levels of estrogen-responsive finger protein (Efp), a cell cyclerelated gene modulated by $\mathrm{ER} \alpha$, that increased to approximately 1.6-fold in cells exposed to $E_{2}$ was suppressed by MSA treatment. These results indicated that MSA may cause the disruption in ER $\alpha$ signaling through decreases in ER $\alpha$ mRNA levels and subsequent protein levels. It is also suggested that cell growth inhibition induced by MSA is related to cell cycle arrest.

Induction of oxidative stress defense system by treatment with $E_{2}$ plus MSA

To clarify whether resistance to oxidative stress induced by MSA was related to inhibition of ER $\alpha$ expression, we investigated the activation of antioxidative enzymes such as GPx1 and TrxR by treat-
(A) ER $\alpha$ mRNA
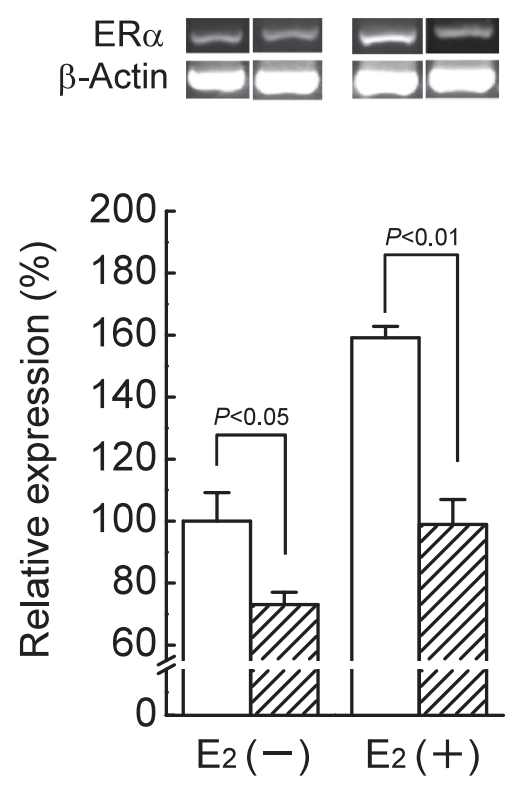

(B) ER $\alpha$ protein
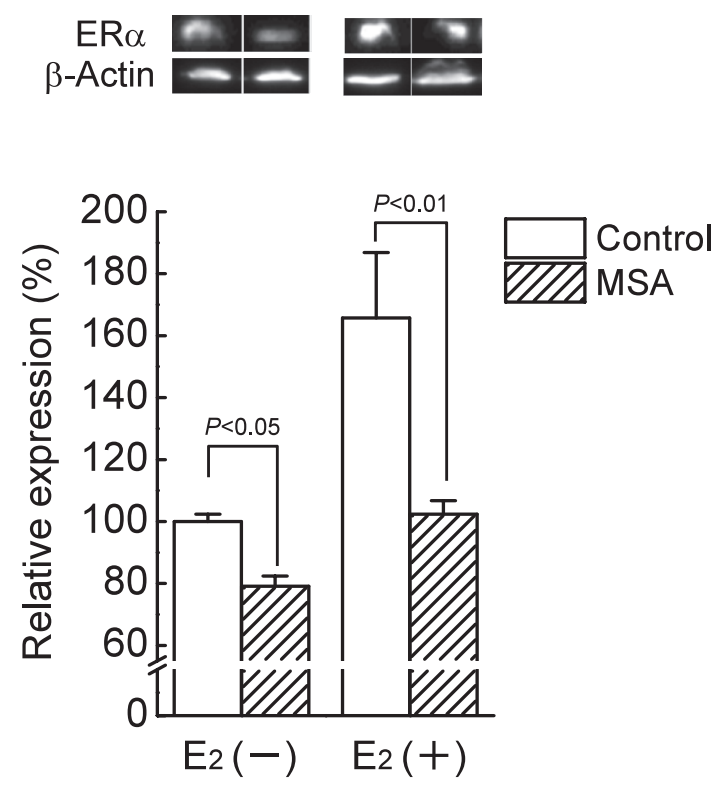

Fig. 2 Effect of $E_{2}$ and MSA on ERa mRNA levels (A) and ERa protein levels (B) in T47D cells. $E_{2}$ and MSA were exposed at concentrations of $1 \times 10^{-9} \mathrm{~mol} / \mathrm{L}$ and $1 \times 10^{-6} \mathrm{~mol} / \mathrm{L}$, respectively. Relative expression of ERa mRNA and ERa protein of untreated controls was taken as $100 \%$, respectively. Values are mean \pm SD $(n=3-5)$. 
ment with $\mathrm{E}_{2}$ and MSA. In T47D cells, GPx1 protein expression and GPx1 activity were hardly detected regardless of treatment with $\mathrm{E}_{2}$ or MSA. Additionally, there was little content of GSH as a coupling factor of GPx1 $(26 \pm 2 \mathrm{nmol} / \mathrm{mg}$ protein). On the other hand, as shown in Fig. 3, MSA significantly increased TrxR protein levels. MSA also increased enzyme activity of TrxR (Fig. 4). In cells exposed to $\mathrm{E}_{2}$, as shown in Fig. 5, Trx protein levels increased to about 1.5 -fold of untreated controls. These results suggest that the Trx/TrxR system plays an important role in the resistance to oxidative stress in T47D cells exposed to both $\mathrm{E}_{2}$ and MSA.

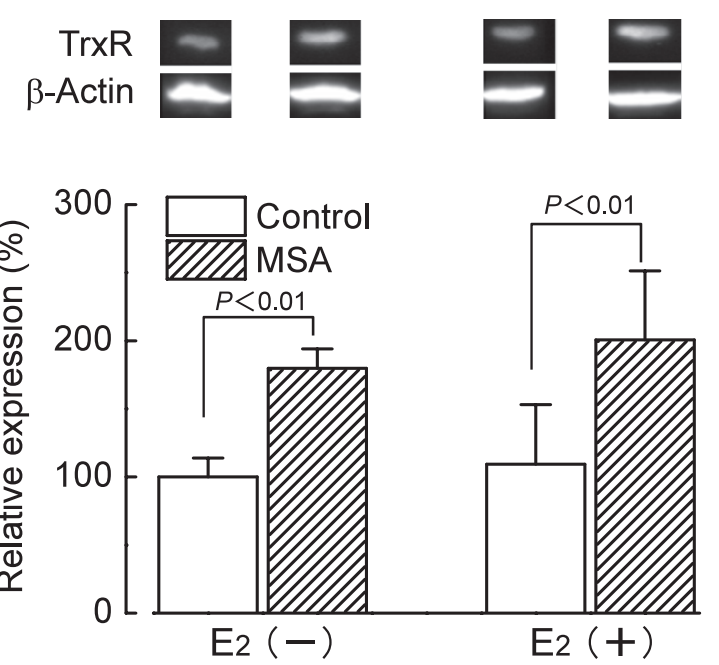

Fig. 3 Effect of $E_{2}$ and MSA on TrxR protein levels in T47D cells. $E_{2}$ and MSA were exposed at concentrations of $1 \times 10^{-9} \mathrm{~mol} / \mathrm{L}$ and $1 \times 10^{-6} \mathrm{~mol} / \mathrm{L}$, respectively. Relative expression of TrxR protein of untreated controls was taken as $100 \%$. Values are mean \pm SD $(n=3-5)$.

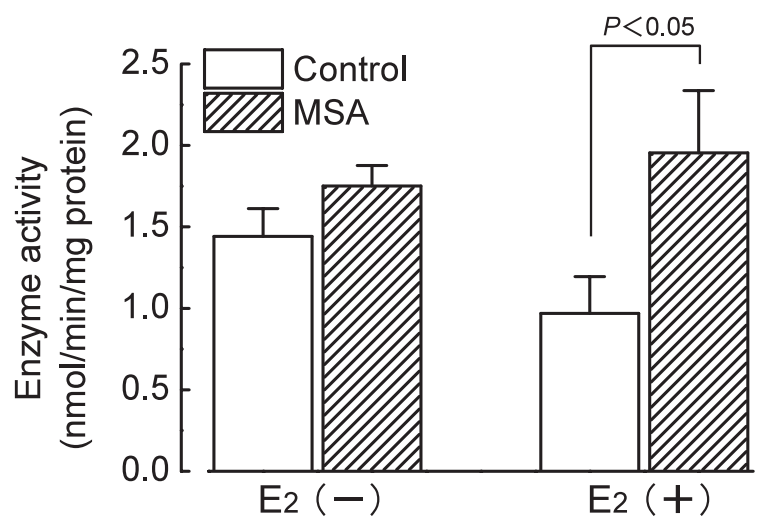

Fig. 4 Effect of $E_{2}$ and MSA on TrxR activity in T47D cells. $E_{2}$ and MSA were exposed at $1 \times 10^{-9} \mathrm{~mol} / \mathrm{L}$ and $1 \times 10^{-6} \mathrm{~mol} / \mathrm{L}$, respectively. Values are mean $\pm S D(n=3-5)$.
Suppression of intracellular ROS generation by MSA

We next examined whether the amount of intracellular ROS generated by $\mathrm{E}_{2}$ metabolism was scavenged by MSA treatment. As shown in Fig. 6, intracellular ROS content in T47D cells after $12 \mathrm{~h}$ and $24 \mathrm{~h}$ treatment of $1 \times 10^{-9} \mathrm{~mol} / \mathrm{L} \mathrm{E}_{2}$ was 1.2 - and 1.5-fold higher than that of untreated controls, respectively. MSA markedly decreased intracellular ROS content induced by $\mathrm{E}_{2}$ treatment (Fig. 6). These results suggest that MSA scavenges $\mathrm{E}_{2}$-induced ROS in T47D cells through an enhanced antioxidant Trx/TrxR system.

\section{DISCUSSION}

As a first step toward elucidation of the mechanisms important for the anticancer activity of Se compounds, we evaluated the growth inhibitory effects of 9 kinds of commercial Se compounds against ER $\alpha$-positive T47D human breast cancer cells in the presence of $E_{2}$. Previous studies have shown that organic Se compounds provide beneficial inhibitory effects on breast cancer cell growth in vitro. Redman et al. (31) reported that selenomethionine inhibited growth of ER $\alpha$-positive MCF-7 cells at concentrations greater than $1 \times 10^{-5} \mathrm{~mol} / \mathrm{L}$. MSA was able to suppress growth of MCF-7 cells at concentrations of $5 \times 10^{-6}$ and $1 \times 10^{-5} \mathrm{~mol} / \mathrm{L}$, whereas $\mathrm{Se}$-methylselenocysteine had no effect (33). MSA

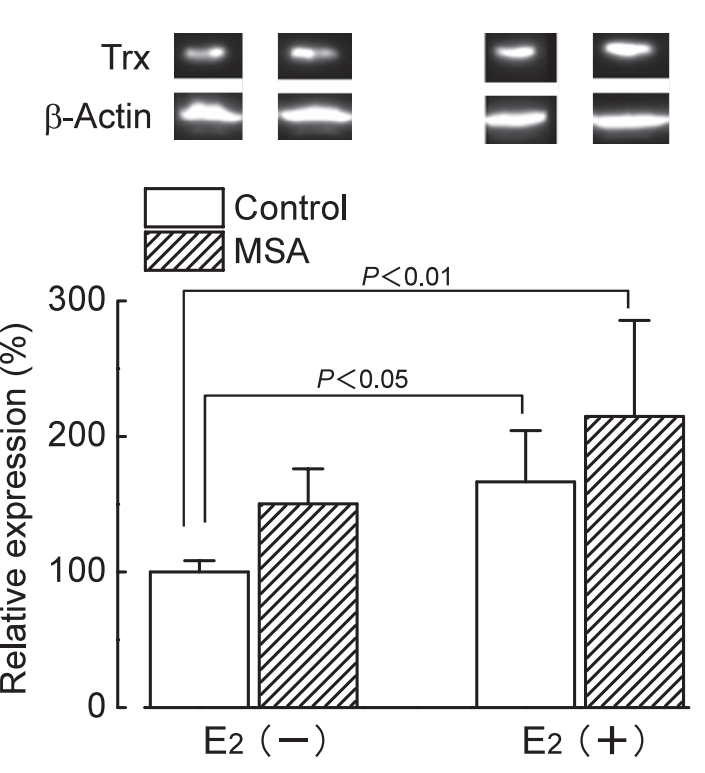

Fig. 5 Effect of $E_{2}$ and MSA on Trx protein levels in T47D cells. $E_{2}$ and MSA were exposed at $1 \times 10^{-9} \mathrm{~mol} / \mathrm{L}$ and $1 \times$ $10^{-6} \mathrm{~mol} / \mathrm{L}$, respectively. Relative expression of Trx protein of untreated controls was taken as $100 \%$. Values are mean \pm SD $(n=3-5)$. 


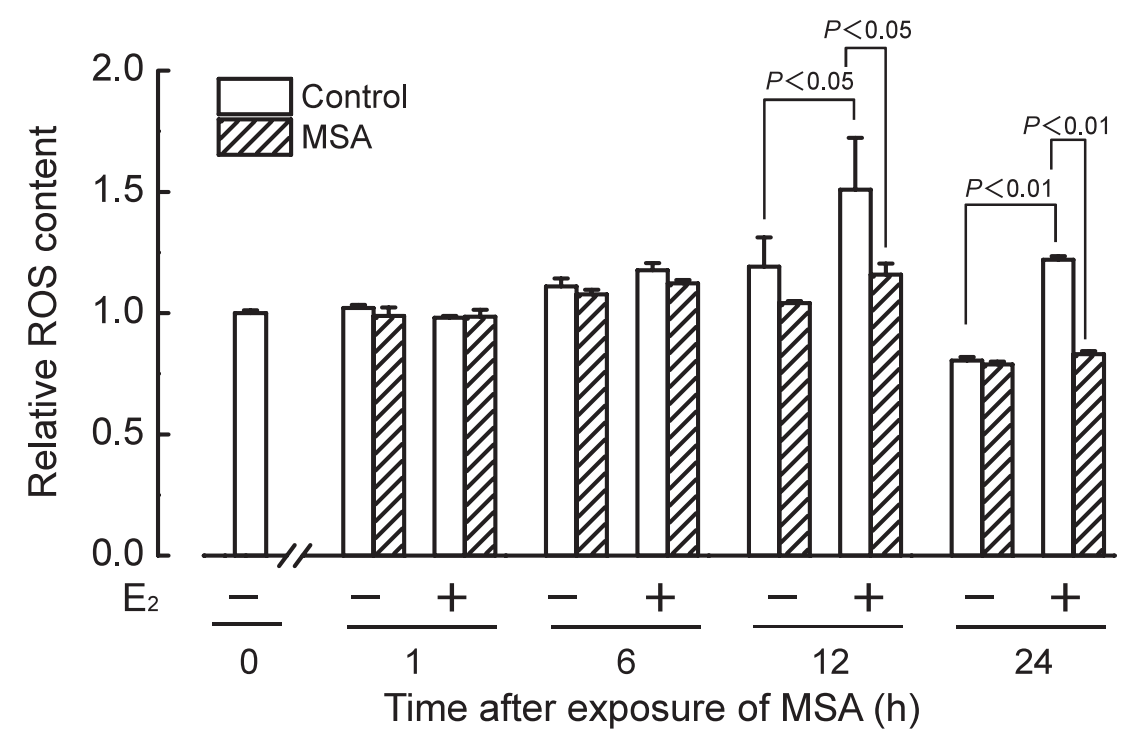

Fig. 6 Effect of $E_{2}$ and MSA on intracellular ROS production in T47D cells. $E_{2}$ and MSA were exposed at $1 \times 10^{-9} \mathrm{~mol} / \mathrm{L}$ and $1 \times 10^{-6} \mathrm{~mol} / \mathrm{L}$, respectively. Relative ROS content of untreated controls was taken as 1.0. Values are mean $\pm \mathrm{SD}$ $(n=3-4)$.

also inhibited growth of noncancerous cells, MCF10AT1 and MCF10AT3B breast epithelial cells, at a concentration range between $2.5 \times 10^{-6}$ and $1 \times$ $10^{-5} \mathrm{~mol} / \mathrm{L}$. However, these doses are slightly higher than human blood levels noted in individuals receiving dietary Se supplements. Moreover, there is a possibility that the response to cell growth inhibition differs with Se forms and cell lines. Previous reports imply that the mechanism of growth inhibition by MSA between T47D cells and other ER $\alpha$-positive breast cancer cells may be different. Until now, the inhibitory effect of various Se compounds against T47D cells is not clear. Our data show that $\mathrm{Na}_{2} \mathrm{SeO}_{3}$, selenomethionine and MSA were sufficient to inhibit $\mathrm{E}_{2}$-dependent cell growth of T47D cells at a concentration of $1 \times 10^{-6} \mathrm{~mol} / \mathrm{L}$ (Table 1$)$. In contrast, no growth inhibitory effects were observed after treatment with other Se compounds at $1 \times 10^{-6} \mathrm{~mol} / \mathrm{L}$ in the presence of $\mathrm{E}_{2}$. Interestingly, the inhibitory action of MSA was stronger than that of both $\mathrm{Na}_{2} \mathrm{SeO}_{3}$ and selenomethionine. We demonstrated, for the first time, that MSA at $1 \times 10^{-6} \mathrm{~mol} / \mathrm{L}$ specifically inhibited only $\mathrm{E}_{2}$-induced cell growth (Fig. 1). These results suggest that the inhibitory action of MSA at $1 \times 10^{-6} \mathrm{~mol} / \mathrm{L}$ may be closely related to $E_{2}-$ induced cellular proliferation.

$\mathrm{E}_{2}$ is known to diffuse across the cell membrane and bind to ERs. ER $\alpha$ and ER $\beta$ show different tissue distributions (26), affinity for coactivators (1), and responses to hormones (25). It is generally recognized that $\mathrm{E}_{2}$ transcriptional activities implicated in breast cancer cell proliferation are mediated through ER $\alpha(35,41)$. A very small percentage of epithelial cells in the normal, adult mammary gland are proliferating and these proliferating cells express very little or no ER $\alpha$. In contrast, epithelial breast cancer cells are ER $\alpha$ positive. The ER $\alpha$ signaling pathway plays an important role in promoting growth of ER $\alpha$-positive breast cancer cells. ER $\alpha$ regulates the transcription of various genes as follows: The $\mathrm{E}_{2}$-ER $\alpha$ complex binds to a specific DNA sequence ERE present in target genes and rapidly induces transcription, which may, in turn, lead to activation of other downstream genes (16). Alternatively, the $\mathrm{E}_{2}$-ER complex can interact with other DNA-bound transcription factors that in turn bind DNA sequences (e.g. via AP-1, SP1 complex) (17, 30). Shah et al. (33) reported that MSA disrupted ER $\alpha$ signaling in MCF-7 cells. Efp, a target gene product of ER $\alpha$, was expressed in human breast cancer cells and $E_{2}$-induced expression of Efp was only found in MCF-7 cells until now (12). Orimo et al. (24) suggested that Efp is essential for estrogen induced cell growth. Efp is a RING-finger-dependent ubiquitin ligase (E3) that targets proteolysis of $14-3-3 \sigma$, a negative cell cycle regulator that causes G2 arrest. (8). In our present study using T47D cells, MSA significantly blocked $\mathrm{E}_{2}$-dependent expression of ER $\alpha$ (Fig. 2), and then reduced expression of Efp. Therefore, we speculate that MSA causes G2 arrest through disruption of the ER $\alpha$ signaling pathway in T47D cells. 


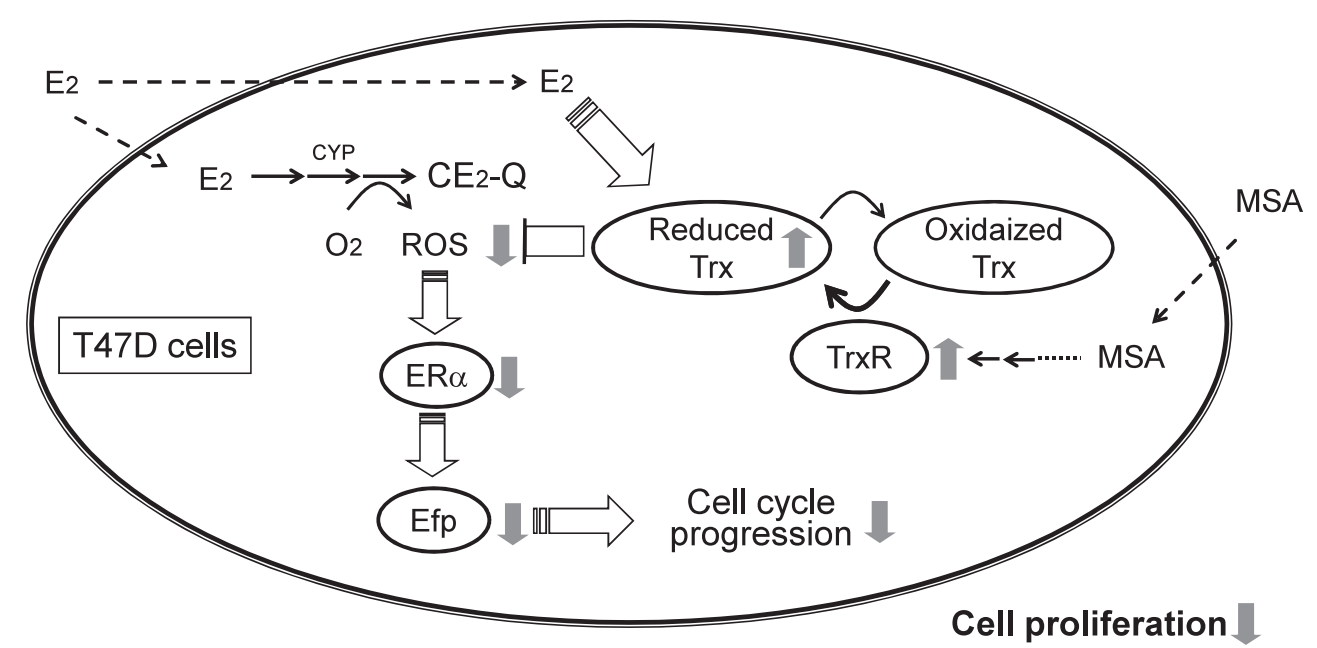

Fig. 7 Proposed suppression mechanism of $E_{2}$-induced T47D cell growth by MSA. $E_{2}: 17 \beta$-estradiol, $C E_{2}-Q$ : catechol $E_{2}$ quinone, CYP: cytochrome P-450, ERa: estrogen receptor $a$, Efp: estrogen receptor finger protein, ROS: reactive oxygen species, MSA: methylseleninic acid, Trx: thioredoxin, TrxR: thioredoxin reductase. $\square$ : Promotion, $\square$ : Inhibition

In addition to inducing cellular proliferation, $\mathrm{E}_{2}$ is also known to increase cell survival by upregulating the antiapoptotic factor bcl-2 (27) and downregulating several proapoptotic factors (7). Meanwhile, a previous report demonstrated MSA-induced growth inhibition in cell lines via induction of apoptosis (14). In the presence of $E_{2}$, induction of apoptosis was hardly observed in T47D cells exposed to MSA at $1 \times 10^{-6} \mathrm{~mol} / \mathrm{L}$ (data not shown). These results suggest that $\mathrm{E}_{2}$-induced cell growth inhibited by MSA was due to arrest of the cell cycle rather than promotion of apoptotic cell death.

MSA markedly decreased ER $\alpha$ expression in T47D cells exposed to $E_{2}$ at a physiological concentration (Fig. 2), but the underlying mechanism has been unknown until now. Physiologically achievable concentrations of $\mathrm{E}_{2}$ generate ROS such as $\mathrm{O}_{2}{ }^{--}$, $\mathrm{H}_{2} \mathrm{O}_{2}$, and $\mathrm{OH}^{\bullet}$ via metabolism in cells (22). ROS have been reported to modulate $\mathrm{ER} \alpha$ expression: low concentrations of $\mathrm{H}_{2} \mathrm{O}_{2}$ increased $\mathrm{ER} \alpha$ protein levels in MCF-7 cells and T47D cells (37). This time, intracellular ROS content increased $12 \mathrm{~h}$ and $24 \mathrm{~h}$ after treatment with $\mathrm{E}_{2}$ at a physiological concentration (Fig. 6). However, coexistence of MSA decreased $\mathrm{E}_{2}$-induced intracellular ROS amounts to untreated control levels (Fig. 6). GSH, a tripeptide thiol of cysteine-glutamine-glycine, and Trx, a small protein that has two cysteines in its active site, are responsible for the antioxidant defense of cells. It has been reported that GSH content in MCF-7 cells was about $75 \mathrm{nmol} / \mathrm{mg}$ protein (43). In contrast, GSH content in T47D cells was $2.6 \pm 0.2 \mathrm{nmol} / \mathrm{mg}$ protein. Expression and activity of GPx1 were not detected in T47D cells regardless of $\mathrm{E}_{2}$ and/or MSA exposure. These results suggest that the GSH/GPx 1 system hardly functions as a scavenger for $\mathrm{H}_{2} \mathrm{O}_{2}$ in T47D cells. It is also known that TrxR is a key player in regulation of the redox state in cells. Oxidized Trx is inactive, but is converted to the active reduced form by TrxR. Trx binds ROS and protects cells against oxidative stress. In T47D cells, MSA at $1 \times 10^{-6} \mathrm{~mol} / \mathrm{L}$ significantly increased not only expression of the TrxR protein, but also enzyme activity of TrxR (Fig. 3 and 4). Moreover, $E_{2}$ at a physiological concentration caused increases in Trx protein levels (Fig. 5). These findings suggest that the Trx/TrxR system is effectively activated by the synergistic action of $\mathrm{E}_{2}$ and MSA, and plays a central role in defense against oxidative stress in T47D cells.

In conclusion, we show that MSA exerted strong antiproliferation activity against ER $\alpha$-positive T47D cells. It is possible that MSA-mediated growth arrest is mediated in part through disruption of estrogen signaling in ER $\alpha$-positive T47D cells. We speculate that one of the inhibitory mechanisms of ER $\alpha$ expression is as follows (Fig. 7). First, in the presence of $E_{2}$, MSA effectively enhances the oxidative stress defense system, the Trx/TrxR system, which increases reduced Trx. The reduced Trx scavenges intracellular ROS generated by $\mathrm{E}_{2}$ metabolism, resulting in suppression of $E R \alpha$ expression in $E R \alpha$-positive cells. Thus, decreases in ER $\alpha$ protein levels cause the disruption of ER $\alpha$ signaling, and inhibits G2/M cell cycle progression through decreases in Efp expression. 


\section{Acknowledgments}

This work was supported by JSPS KAKENHI Grant Number 18790385 . The authors are grateful to Mr. S. Fukawa and Ms. N. Shigeta for their expert technical assistance.

\section{REFERENCES}

1. Acevedo ML and Kraus WL (2003) Mediator and p300/CBPsteroid receptor coactivator complexes have distinct roles, but function synergistically, during estrogen receptor alphadependent transcription with chromatin templates. Mol Cell Biol 23, 335-348.

2. Bass DA, Parce JW, Dechatelet LR, Szejda P, Seeds MC and Thomas M (1983) Flow cytometric studies of oxidative product formation by neutrophils: a graded response to membrane stimulation. J Immunol 130, 1910-1917.

3. Clark LC, Combs GF Jr, Turnbull BW, Slate EH, Chalker DK, Chow J, Davis LS, Glover RA, Graham GF, Gross EG, Krongrad A, Lesher JL Jr, Park HK, Sanders BB Jr, Smith CL and Taylor JR (1996) Effects of selenium supplementation for cancer prevention in patients with carcinoma of the skin. A randomized controlled trial. Nutritional Prevention of Cancer Study Group. JAMA 276, 1957-1963.

4. Dickson RB and Lippman ME (1987) Estrogenic regulation of growth and polypeptide growth factor secretion in human breast carcinoma. Endocr Rev 8, 29-43.

5. Duffield-Lillico AJ, Reid ME, Turnbull BW, Combs GF Jr, Slate EH, Fischbach LA, Marshall JR and Clark LC (2002) Baseline characteristics and the effect of selenium supplementation on cancer incidence in a randomized clinical trial: a summary report of the Nutritional Prevention of Cancer Trial. Cancer Epidemiol Biomarkers Prev 11, 630-639.

6. Evans RM (1988) The steroid and thyroid hormone receptor superfamily. Science. 240, 889-895.

7. Frasor J, Danes JM, Komm B, Chang KC, Lyttle CR and Katzenellenbogen BS (2003) Profiling of estrogen up- and down-regulated gene expression in human breast cancer cells: insights into gene networks and pathways underlying estrogenic control of proliferation and cell phenotype. Endocrinology 144, 4562-4574.

8. Hermeking H, Lengauer C, Polyak K, He TC, Zhang L, Thiagalingam S, Kinzler KW and Vogelstein B (1997) 14-3-3 sigma is a p53-regulated inhibitor of $\mathrm{G} 2 / \mathrm{M}$ progression. $\mathrm{Mol}$ Cell 1, 3-11.

9. Hill KE, McCollum GW, Boeglin ME and Burk RF (1997) Thioredoxin reductase activity is decreased by selenium deficiency. Biochem Biophys Res Commun 234, 293-295.

10. Hirabayashi Y and Zhang M (2009) Comparison of time trends in breast cancer incidence (1973-2002) in Asia, from cancer incidence in five continents, Vols IV-IX. Jpn J Clin Oncol 39, 411-412

11. Holmgren A and Björnstedt M (1995) Thioredoxin and thioredoxin reductase. Methods Enzymol 252, 199-208.

12. Ikeda K, Orimo A, Higashi Y, Muramatsu M and Inoue S (2000) Efp as a primary estrogen-responsive gene in human breast cancer. FEBS Lett 472, 9-13.

13. Jakacka M, Ito M, Weiss J, Chien PY, Gehm BD and Jameson JL (2001) Estrogen receptor binding to DNA is not required for its activity through the nonclassical AP1 pathway. $J$ Biol Chem 276, 13615-13621.

14. Jiang C, Wang Z, Ganther H and Lu J (2001) Caspases as key executors of methyl selenium-induced apoptosis (anoikis) of DU-145 prostate cancer cells. Cancer Res 61, 3062-3070.

15. Key T, Appleby P, Barnes I and Reeves G; The Endogenous Hormones and Breast Cancer Collaborative Group (2002) Endogenous sex hormones and breast cancer in postmenopausal women: Reanalysis of nine prospective studies. $J$ Natl Cancer Inst 94, 606-616.

16. Klinge CM (2001) Estrogen receptor interaction with estrogen response elements. Nucleic Acids Res 29, 2905-2919.

17. Kushner PJ, Agard DA, Greene GL, Scanlan TS, Shiau AK, Uht RM and Webb P (2000) Estrogen receptor pathways to AP-1. J Steroid Biochem Mol Biol 74, 311-317.

18. Kyprianou N, English HF, Davidson NE and Isaacs JT (1991) Programmed cell death during regression of the MCF-7 human breast cancer following estrogen ablation. Cancer Res 51, 162-166.

19. Lau KM, Mok SC and Ho SM (1999) Expression of human estrogen receptor-alpha and -beta, progesterone receptor, and androgen receptor mRNA in normal and malignant ovarian epithelial cells. Proc Natl Acad Sci USA 96, 5722-5727.

20. Matsuda T, Marugame T, Kamo K, Katanoda K, Ajiki W and Sobue T; Japan Cancer Surveillance Research Group (2012) Cancer incidence and incidence rates in Japan in 2006: Based on data from 15 population-based cancer registries in the Monitoring of Cancer Incidence in Japan (MCIJ) project. Jpn $J$ Clin Oncol 42, 139-147.

21. Medina D, Lane HW and Shepherd F (1983) Effect of dietary selenium levels on 7,12-dimethylbenzanthraceneinduced mouse mammary tumorigenesis. Carcinogenesis $\mathbf{4}$, $1159-1163$.

22. Okoh V, Deoraj A and Roy D (2011) Estrogen-induced reactive oxygen species-mediated signalings contribute to breast cancer. Biochim Biophys Acta 1815, 115-133.

23. Olea N, Pulgar R, Pérez P, Olea-Serrano F, Rivas A, NovilloFertrell A, Pedraza V, Soto AM and Sonnenschein C (1996) Estrogenicity of resin-based composites and sealants used in dentistry. Environ Health Perspect 104, 298-305.

24. Orimo A, Inoue S, Minowa O, Tominaga N, Tomioka Y, Sato M, Kuno J, Hiroi H, Shimizu Y, Suzuki M, Noda T and Muramatsu M (1999) Underdeveloped uterus and reduced estrogen responsiveness in mice with disruption of the estrogen-responsive finger protein gene, which is a direct target of estrogen receptor alpha. Proc Natl Acad Sci USA 96, 12027 12032.

25. Paech K, Webb P, Kuiper GG, Nilsson S, Gustafsson J, Kushner PJ and Scanlan TS (1997) Differential ligand activation of estrogen receptors ERalpha and ERbeta at AP1 sites. Science 277, 1508-1510.

26. Palmieri C, Cheng GJ, Saji S, Zelada-Hedman M, Wärri A, Weihua Z, Van Noorden S, Wahlstrom T, Coombes RC, Warner M and Gustafsson JA (2002) Estrogen receptor beta in breast cancer. Endocr Relat Cancer 9, 1-13.

27. Perillo B, Sasso A, Abbondanza C and Palumbo G (2000) 17 beta-estradiol inhibits apoptosis in MCF-7 cells, inducing bcl-2 expression via two estrogen-responsive elements present in the coding sequence. Mol Cell Biol 20, 2890-2901.

28. Prall OW, Sarcevic B, Musgrove EA, Watts CK and Sutherland RL (1997) Estrogen-induced activation of Cdk4 and Cdk2 during G1-S phase progression is accompanied by increased cyclin D1 expression and decreased cyclin-dependent kinase inhibitor association with cyclin E-Cdk2. J Biol Chem 272, 10882-10894.

29. Prall OW, Rogan EM, Musgrove EA, Watts CK and Sutherland RL (1998) c-Myc or cyclin D1 mimics estrogen effects on 
cyclin E-Cdk2 activation and cell cycle reentry. Mol Cell Biol 18, 4499-4508.

30. Qin C, Singh P and Safe S (1999) Transcriptional activation of insulin-like growth factor-binding protein-4 by $17 \mathrm{beta}$ estradiol in MCF-7 cells: role of estrogen receptor-Sp1 complexes. Endocrinology 140, 2501-2508.

31. Redman C, Scott JA, Baines AT, Basye JL, Clark LC, Calley C, Roe D, Payne CM and Nelson MA (1998) Inhibitory effect of selenomethionine on the growth of three selected human tumor cell lines. Cancer Lett 125, 103-110.

32. Sakazaki, H, Ueno H, Umetani K, Utsumi H and Nakamuro $\mathrm{K}$ (2001) Immunotoxicological evaluation of environmental chemicals utilizing mouse lymphocyte mitogenesis test. $J$ Health Sci 47, 258-271.

33. Shah YM, Kaul A, Dong Y, Ip C and Rowan BG (2005) Attenuation of estrogen receptor alpha (ERalpha) signaling by selenium in breast cancer cells via downregulation of ERalpha gene expression. Breast Cancer Res Treat 92, 239-250.

34. Shin HR, Boniol M, Joubert C, Hery C, Haukka J, Autier P, Nishino Y, Sobue T, Chen CJ, You SL, Ahn SH, Jung KW, Law SC, Mang O and Chia KS (2010) Secular trends in breast cancer mortality in five East Asian populations: Hong Kong, Japan, Korea, Singapore and Taiwan. Cancer Sci 101, 1241-1246.

35. Sun JM, Chen HY and Davie JR (2001) Effect of estradiol on histone acetylation dynamics in human breast cancer cells. $J$ Biol Chem 276, 49435-49442.
36. Sutherland RL, Prall OW, Watts CK and Musgrove EA (1998) Estrogen and progestin regulation of cell cycle progression. $J$ Mammary Gland Biol Neoplasia 3, 63-72.

37. Tamir S, Izrael S and Vaya J (2002) The effect of oxidative stress on ERalpha and ERbeta expression. J Steroid Biochem Mol Biol 81, 327-332.

38. Toyo'oka T and Imai K (1983) High-performance liquid chromatography and fluorometric detection of biologically important thiols, derivatized with ammonium 7-fluorobenzo2-oxa-1,3-diazole-4-sulphonate (SBD-F). J Chromatogr 282, $495-500$.

39. Tsai MJ and O’Malley BW (1994) Molecular mechanisms of action of steroid/thyroid receptor superfamily members. Annu Rev Biochem, 63, 451-486.

40. Wang TT and Phang JM (1995) Effects of estrogen on apoptotic pathways in human breast cancer cell line MCF-7. Cancer Res 55, 2487-2489.

41. Weihua Z, Lathe R, Warner M and Gustafsson JA (2002) An endocrine pathway in the prostate, ERbeta, AR, 5alpha-androstane-3beta,17beta-diol, and CYP7B1, regulates prostate growth. Proc Natl Acad Sci USA 99, 13589-13594.

42. Yamamoto Y and Takahashi K (1993) Glutathione peroxidase isolated from plasma reduces phospholipid hydroperoxides. Arch Biochem Biophys 305, 541-545.

43. Zhang Y (2001) Molecular mechanism of rapid cellular accumulation of anticarcinogenic isothiocyanates. Carcinogenesis 22, 425-431. 